Article

\title{
Can Narrative Advertisement and eWOM Influence Generation Z Purchase Intentions?
}

\author{
Sidra Tabassum ${ }^{1}$, Muddasar Ghani Khwaja ${ }^{1}$ and Umer Zaman ${ }^{2, *([)}$ \\ 1 Faculty of Management Sciences, Shaheed Zulfikar Ali Bhutto Institute of Science and Technology, \\ Islamabad 44000, Pakistan; sidratabassum0@gmail.com (S.T.); muddasar.ghani@szabist-isb.edu.pk (M.G.K.) \\ 2 Endicott College of International Studies (ECIS), Woosong University, Dong-gu 34606, Korea \\ * Correspondence: umerzaman@endicott.ac.kr
}

Received: 30 September 2020; Accepted: 23 November 2020; Published: 25 November 2020

\begin{abstract}
Digital platforms have made Generation $Z$ able to listen to the story from both sides, i.e., the brand's promotional messages, and the consumers' experiences. To capture an audience's attention on endless entertainment and informational platforms, narrative advertisement is deployed to trigger emotions and feelings. As digital communities continue to grow, both brands and consumers are using narrative advertising to share their opinions. Hence, the purpose of this research was to investigate how the upcoming generation of consumers will be affected by the two information sources, i.e., the brands via narrative advertising, and peer consumers through electronic word-of-mouth (eWOM). Furthermore, the mediated role of persuasion knowledge was examined among the constructs. Theoretical foundations were empirically tested using quantitative research analysis. The data was collected from a sample of 304 Generation $Z$ respondents from Pakistan. Structural equation modeling (SEM) using AMOS 22.0 was executed to determine cause and effect relationships. This study offers new evidence regarding the effective mobilization of eWOM and narrative advertising in the context of Generation Z. The results indicate narrative advertising to have strong effects on Generation Z purchase intentions as compared to eWOM.
\end{abstract}

Keywords: narrative advertising; electronic word-of-mouth; purchase intentions; Generation Z

\section{Introduction}

The recent innovative developments have mobilized the marketing efforts of global firms to spark the excitement of digital natives (i.e., Generation Z) with real-time and narrative content [1,2]. The possession of distinct beliefs, preferences, and values is engraved in almost every generational cohort which eventually forms different behaviors. These evolving dynamics have led marketers on diverse marketing strategies, as a generic marketing mantra would not be impactful for all generations [3]. Each generation witnesses its unique technological evolution, one generational cohort could prefer the experience of brick-and-mortar where they can touch and feel the products, while another might prefer the convenience of an online retailing store [4,5]. Bashir et al., [4] suggested that each generation has its own way of shopping, time allocation for it, and selection of brick-and-mortar or online store and that brands must adapt to it accordingly. Chu and Kim [6] explained that while recognizing the generational differences, brands may change their hedonic/utilitarian use of digital platforms and tools, the data sources they employ, the influence of these platforms on a purchase, and different payment options. The upcoming generation of consumers that marketers need to focus on is Generation Z. Generation Z or "Digital X" is the generational cohort of consumers born between 1995 and the late 2000s [7]. Generation $Z$ is the first generation to grow up with technology from their early childhood years, there they are more sophisticated in terms of connectivity and information as compared to any 
prior generation ever [8]. They are relatively intense users of digital platforms and tools, concerning the number of hours spent and the number of platforms they use as well [9].

Narrative or storytelling ads are one example of such ads that tend to generate stronger emotional responses and consumer engagement [10]. Recent studies on narrative advertising found that story ads are more probable to trigger emotions in viewers, also facial coding has shown that there are more chances that viewers will give expressions while watching a narrative format ad [11,12]. Generation $\mathrm{Z}$ use more digital channels as compared to their predecessors and their attention is divided between various devices and they prefer quick solutions as they have unlimited information access [13]. Thus, advertising to Generation $\mathrm{Z}$ is different from other generations. They like the brands and products in which they can see their reflection, and prefer realistic and relatable content. Narrative advertising can make consumers imagine themselves experiencing the given product or service [14]. Henceforth, narrative ads must be investigated in the case of Generation $\mathrm{Z}$ as they are an upcoming larger market segment. More and more brands are using narrative advertising to trigger emotional responses in their audience and given the Gen $\mathrm{Z}$ online traits and habits, the narrative advertisement could be useful to capture their attention [15-17]. The effect of both eWOM and narrative advertisements simultaneously on purchase intentions needs to be measured as both constructs have different conceptions and themes. Through the mediation effects of persuasion knowledge, it would be interesting to determine whether eWOM or narrative advertisement has a more powerful effect on purchase intentions.

Contextually, Pakistan is one of Asia's rapidly growing e-commerce markets [18]. As of July 2020, the Pakistan telecommunication authority (PTA) states that there are 81 million 3G and 4G users in Pakistan [19]. Moreover, there are 83 million broadband users in the country. Meanwhile, the overall cellular subscribers in Pakistan are 167 million. According to Hootsuite [20], there are 76.38 million internet users in Pakistan. As of January 2020, internet penetration in Pakistan has exceeded $35 \%$. Furthermore, there are almost 37 million social media users in Pakistan. In the case of social media users, Pakistan has a $35 \%$ yearly growth as compared to a $21 \%$ global average. Moreover, as the numbers of consumers using digital media continue to increase, brands have also followed the trend and almost every major brand in Pakistan has a social media presence. Henceforth, due to the aforementioned factors, the investigation of such a study in the Pakistani context is pertinent.

Nguyen, [21] employed only Facebook respondents to investigate the electronic word of mouth (eWOM) effect on electronic product consumers, as the scope of advertising has been widened by social media platforms, more and more marketers are using digital advertising thus the effectiveness of eWOM must also be investigated on other platforms. Khwaja and Zaman [22] also proposed further investigation should be done using different online users falling into diverse age categories and taking other categories of products other than the smartphone to be examined for future research. This could be extended to examine the eWOM impact on generation $\mathrm{Z}$ on multiple digital platforms. Menon et al. [23] limited their research to Twitter posts on airline companies and suggested extending the work to other industries and social media platforms. Considering the aforementioned factors, it is theorized that since Generation $Z$ grew up with unique values, beliefs, socio-cultural, technological, and economic environment; thus, their buying behaviors are divergent and need to be investigated. The purpose of this paper is to examine how narrative advertisement and electronic word of mouth (eWOM) are affecting the purchase intentions of Generation Z. Furthermore, also to explore how persuasion knowledge mediates between narrative advertisement and purchase intentions.

The study is oriented to determine how persuasion knowledge would be mediating between narrative advertising, electronic word-of-mouth and the purchase intentions of Generation Z. Positivist research philosophy has been deployed using a deductive approach for the determination of causality. Quantitative research using survey techniques were executed for the collection of data. Statistical analysis using structural equation modeling (SEM) techniques was deployed to precisely measure theoretical association among the constructs. 


\section{Literature Review}

\subsection{Narrative Advertising}

Narrative advertising is defined as conveying core messages to the customers by telling a story. Globally, narrative advertising and storytelling techniques are deployed in marketing campaigns [24,25]. An advertisement that presents information regarding a product or service in a narrative form is more likely to get a positive evaluation by the audience as compared to the advertisement presenting information more straightforwardly. The principle of storytelling lies in the fact that the human mind stores information in a story format. Liang and Tukachinsky [25] differentiated narrative or non-narrative as non-narrative lack such a narratively arched sequence of linked events and character development; instead, they may present information in a more list-like format or using generalized arguments. Narrative advertising generally depicts the product or service use and its aftercoming or constitutes plots showing the individual's wishes, for instance, accomplishment or adventure [26].

Stories are the essence of human life, Bashir et al. [26] explained that throughout our lives we learn and build ourselves through stories. In an advertising context, many researchers have established the fact that narrative format ads perform better than non-narrative or argumentative ads [27-29]. Researchers have also established that narratives are more persuasive and influence the attitude of the audience [30,31] and behavioral intentions [32-34] and generate more positive feelings, less negative cognitive responses, and favorable advertisement and brand attitude [35].

Contemporary research studies indicate that digital platforms and tools have ended the era of interruptive advertising and have let consumers take control of when and where to let advertisers interrupt their entertainment [36]. As a result, advertisers are looking for distinct ways to advertise and entertain customers $[37,38]$. Furthermore, due to changing consumer shopping patterns, consumers can be landed onto the online shop with a more detailed product description and purchase options, just with a single click on the digital ad. Nevertheless, the actual challenge for the advertisers remains that the digital ad should resonate with consumers and thereby capture their attention [39-41].

Kim, Maslowska, and Malthouse, [42] stated that watching a narrative makes customers imagine themselves experiencing the given product or service, thus make them absorbed into the story, which could further influence customers' brand attitudes and behavioral intentions. Liang and Tukachinsky [25] researched to examine the effect of narrative reviews on digital platforms when written by an expert and found that the narrative format influences the attitude of the reader more as compared to a non-narrative review. Von Helversen, et al. [43] found that narrative ads generate greater advertising message involvement when compared with a factual ad format. Narrative advertising triggers more emotions in the audience thus can be used by advertisers to create positive emotional affiliations with brands [44].

Lal and Rathore, [45] explored the utility of television commercials in their research to find the influence of narrative ads. As digitization has revolutionized the marketing arena, it would be insightful to investigate the effectiveness of narrative advertising using digital platforms. Mahmood et al. [7] suggested investigating how peers influence teenagers' attitudes towards online narrative advertising, and ultimately their brand attitude thus allowing investigating eWOM influence on the purchases of Generation Z. Bashir et al. [3] emphasized that marketers must investigate to gain a better perspective of consumption patterns of different generations, and how various marketing strategies impact each generation's purchasing behavior.

\subsection{Electronic Word-of-Mouth (eWOM)}

Electronic word-of-mouth is defined as the consumers' behavior of exchanging the product or service-related information with other consumers in various digital communities [46]. The term eWOM is also explained as an opinion or experience whether favorable or not when shared by a current, former, or potential customer about a product or brand using any digital platform that has a wider 
reach to other consumers [47]. Khwaja et al. [48] explained eWOM as information sharing between two or more than two consumers regarding a product.

Prior research studies have shown that various forms of eWOM positively influence trust among the audience [49], affect consumer attitudes [50], trigger behavioral intentions [51-53], and readiness to pay [54]. Ansary and Hashim [55] emphasized that many important consumer decisions are influenced by eWOM, such as the decisions involved in which product or service to purchase. Digital consumers are more aware and have access to a bigger pool of information that helps eWOM become an effective and powerful advertising tool, hence many researchers have investigated its impact on consumer decision making $[56,57]$.

Hussain et al. [58] found that consumers frequently consult online reviews and recommendations while considering a purchase option. The reviews and recommendations of other users that project their attitude towards the product reduce ambiguity in the potential consumer about product quality and attributes and hence reduce risk to facilitate purchasing product decisions [59]. The experience and trustworthiness reflected in an online review influence the significance of eWOM that affects attitude and induce purchase intention [60]. Kudeshia and Kuma [61] found that when favorable reviews and recommendations were given by other users on social media it positively influenced the brand attitude and purchase intention of the reader. Khwaja et al. [62] found a positive impact on a company's stock returns by favorable eWOM in social communities.

\subsection{Activation and Use of Persuasion Knowledge}

Persuasion knowledge represents a consumer's beliefs about the motives underlying the marketing message, the message creator's ability to gain benefit from the message, the appropriateness of specific persuasion tactics, and how to evaluate the value attached to the marketing message [63]. The persuasion knowledge of the consumer is defined as the supposition of the consumer about persuasion, which includes their beliefs regarding the power and appropriateness of the marketing message intention and tactics, along with the ways to resist these persuasion attempts [62]. Further studies describe a consumer with high persuasion knowledge as the individual who can figure out easily when a marketing message is pushing their decision and can identify different marketing tactics used by advertisers.

In this information era, consumers can acquire more prenegotiation information than ever before and this expertise makes them more prone to marketing messages [62]. Among the main elements that contribute to such expertise in the consumer is persuasion knowledge [64]. Zheng and Watts, [65] suggested that by activation and usage of persuasion knowledge a consumer can identify that a marketer is trying to push or manipulate the consumer's decision in their favor. Moreover, consumers learn persuasion knowledge over time, and it can be enhanced. Studies elaborated that improving persuasion knowledge helps in making better decisions and in financial understanding. In the case of digital communications, persuasion knowledge helps in evaluating the reviews and recommendations as to whether they are unbiased or not and helps in reducing vulnerability to such persuasive motives [66].

Friestad and Wright, [66] presented their persuasion knowledge model in the early 1990s, in which they described persuasion knowledge as a person's ability to identify advertising material and to recognize its persuasive motives. A consumer's persuasion knowledge develops over time and it can be activated whenever a consumer is exposed to a marketing message [67]. The use and activation of persuasion knowledge enable the viewer to critically evaluate the content of a marketing message and to identify the persuasive tactics and strategies used by marketers in the advertising material [68].

In the online advertising context, researchers suggested that when consumers were being informed that they were viewing sponsored material or advertisements, it did not make them more critical. The study of Reijmersdal, Lammers, Rozendaal, and Buizen [69] found that through the intervening mechanism of persuasion knowledge, such disclosures led to higher brand recall. There is some evidence that long disclosures can foster persuasion knowledge, which leads to less favorable brand attitudes [70]. When marketers give disclosure of marketing material the activation of persuasion 
knowledge occurs and that facilitates better attention to the brand placement and increases memory of the brand [71,72], while some researchers found that persuasive attempts of marketing messages to consumers with better persuasion knowledge could trigger an unfavorable attitude regarding the advertised product [73]. Researchers like Hamby and Brinberg, [74] also suggested that when persuasion knowledge was activated among consumers it could lead to counterarguing, and afterward to an unfavorable brand attitude.

\subsection{Purchase Intention of Generation Z}

Every generational cohort goes through unique circumstances and events which constitute unique values, beliefs, and preferences that define their behavior and attitudes. Generation $\mathrm{Z}$ is the generational cohort of consumers born between 1995 and the late 2000s [75]. Their predecessor, the Millennials (Generation Y), was technology-driven but Generation $\mathrm{Z}$ is the first generation to grow up with technology from childhood. Generation $Z$ is the most connected via the internet, an educated and sophisticated generation ever. The members of Generation $Z$ spend significant periods using digital communities and tools as well as using multiple social communities [76].

Many researchers elucidate Generation $\mathrm{Z}$ in terms of their social media habits such as Generation $Z$ that is born between 1995 and 2009, has a significant role in technology in their daily lives, and spends large amounts of time using social media channels on their smart gadgets [77]. Khwaja [78] found that marketers can better engage Generation $\mathrm{Z}$ on social media and can influence their buying decisions better through digital platforms. Generation $Z$ follows celebrities on digital media and buys products that are endorsed by them on social media. Similarly, it was found that celebrity endorsement on digital platforms results in more consumer attention than any other digital medium marketing. The study examines purchase intentions as an attitudinal construct. The behavioral aspect of purchase behavior can be further explored; however, the current study restricts it to the purchase intentions context [79]. The orientation thus remains to understand how narrative advertising and eWOM can change Generation Z's buying intentions.

\subsection{Theoretical Associations among Constructs}

Narrative advertisement triggers self-referencing and identification with the principle characters [79]. In recent times, the attention spans of consumers are deteriorating at a rapid pace [80]; also, Generation Z not only has a shorter attention span; they also juggle more screens. Thus, the effectiveness of narrative $[80,81]$ could be investigated in Gen. $Z$.

Hypothesis 1 (H1). Narrative advertisement will positively influence the purchase intentions of Gen. Z.

Generation $\mathrm{Z}$ is a hyperconnected generation [81]. The latest Nielsen reports show two-thirds of consumers trust other consumer's reviews and recommendations posted on several digital platforms and is the third most trusted medium. Hussain et al. [58] emphasized that many important consumer decisions are influenced by eWOM, such as the decisions involved in which product or service to purchase. Hence the following hypothesis is proposed:

Hypothesis 2 (H2). Electronic word-of-mouth will positively impact the purchase intentions of Gen Z.

It has been established by several researchers that information presented in narrative format has more influence on the audience's attitudes and beliefs [25,30], behavioral intentions [22,26], fosters positive emotions [34] and causes fewer counterarguments [7], while activation of persuasion knowledge plays a strong role in driving the consumer's decision-making process [82]. Kim et al. [42] in their research suggested that the process mechanism of narrative ads can be studied with the mediation role of activation of persuasion knowledge. The following theoretical connections are hypothesized: 
Hypothesis 3 (H3). There will an influence of narrative advertisement on the activation of persuasion knowledge.

Heejae and Dahana [82] concluded that positive eWOM messages lead to consumer buying behaviors, while negative eWOM messages reduce the consumer's intention to buy products and services. Besides, Khwaja et al. [13], elucidated that the information adoption patterns of individuals tend to alter if the strength of eWOM is weak. Farzin and Fattahi, [53] suggested that in the case of digital platforms where consumers (who are strangers to one another), communicate; the element of uncertainty is naturally inherent in these settings as if the author of the review is an unbiased consumer or a biased marketing source. By considering the aforementioned theoretical associations, the following hypothesis is proposed:

Hypothesis 4 (H4). There will be an influence of eWOM on the activation of persuasion knowledge.

This recent digital landscape has made consumers able to acquire better prenegotiation information than ever before [78]. Consumers have an unlimited stream of information and brand alternatives. This information era allows consumers access to whether a marketing message is too good to be believed. Thus, in Generation Z how activation of persuasion knowledge affects their purchase intention needs to be explored. The following hypothesis is proposed:

Hypothesis 5 (H5). Activation of persuasion knowledge will influence the purchase intention of Gen Z.

Furthermore, the following two hypotheses are proposed to examine the mediating role of the activation of persuasion knowledge on the relationship of narrative advertising and eWOM with the purchase intention of Gen Z.

Hypothesis 6 (H6). The activation of persuasion knowledge will mediate the relationship of narrative advertising and the purchase intention of Gen Z.

Hypothesis 7 (H7). The activation of persuasion knowledge will mediate the relationship of eWOM and the purchase intention of Gen Z.

\section{Materials and Methods}

This research follows a descriptive research design that relates to the projection of participants' experiences. Descriptive research designs are often used by marketers to investigate the traits and habits of consumers. The research followed a positivist philosophy and deployed a deductive approach. Quantitative research was conducted using a structured questionnaire. The research instrument was designed by ensuring that the validity and reliability of all the adapted scales were in the acceptable range. The research instrument comprised twenty-five items and they were evaluated on a 5-point Likert scale. Five items of narrative advertising were adapted from the study of Burnkant and Unnava [83], three items of activation of persuasion knowledge were adapted from the study of Rozendaal, et al. [84], ten items of eWOM were adapted from the study of Zhang and Watts [65], and five items of purchase intentions were adapted from the study of Duffett [1]. The unit of analysis for this study were individuals who belong to Generation Z, involved in online buying in Pakistan. A nonprobability convenience sampling technique was used for the collection of data. The respondents of the study were students studying in different universities in Pakistan. The data was collected offline, by visiting the campuses. For the affirmation of established theoretical association, the SEM technique was deployed. Covariance-based SEM (CB-SEM) using AMOS 22.0 was used as it ensured advanced statistical data modeling in the determination of causal relationships among constructs. Examining data normality, exploratory factor analysis, confirmatory factor analysis, constructs reliability, discriminant, 
and convergent validity $[85,86]$, and multicollinearity determination were mandatory before testing hypotheses in CB-SEM [87-91]. According to Zaman et al. [92], a sample size of more than 200 respondents is ample for SEM. Meanwhile, a few researchers have suggested a sample size of more than 250 is sufficient for configuring statistical path modeling [88]. Hence, the data was collected from 304 respondents.

Most of the respondents were female, 173, with a valid percentage of $56.9 \%$, whereas male respondents were 131, with a valid percentage of $43.1 \%$. As the data was collected from Generation $\mathrm{Z}$ respondents, therefore, $90 \%$ of the respondents were within the age limits of $18-23$ years $(90 \%)$, while $9.9 \%$ of the respondents were under 18 years old. The internet usage frequency of this generation was found to be extensively high. Some $83.6 \%$ of respondents used the internet at least once a day, while almost $11 \%$ of respondents used the internet at least once in seven days. The internet shopping frequency revealed that around $35 \%$ of respondents purchased products once in 30 days, while $26.3 \%$ bought products online once in 90 days. Table 1 provides a complete reflection of the respondents' demographic outcomes.

Table 1. Sample demographics $(n=304)$.

\begin{tabular}{cccc}
\hline Items & & Frequency & Percentage \\
\hline \multirow{2}{*}{ Gender } & Female & 173 & $56.9 \%$ \\
Age & Male & 131 & $43.1 \%$ \\
& Under 18 years & 30 & $9.9 \%$ \\
Internet usage frequency & $18-23$ years & 274 & $90.1 \%$ \\
& Once a day & 233 & $83.6 \%$ \\
Online shopping frequency & Once a week & 33 & $10.9 \%$ \\
& Once a month & 10 & $3.3 \%$ \\
& Not even once a month & 7 & $2.3 \%$ \\
& Less than once in six months & 19 & $6.3 \%$ \\
& Once every six months & 73 & $24.0 \%$ \\
& Once every three months & 80 & $26.3 \%$ \\
& Once a month & 106 & $34.9 \%$ \\
& Once a week & 26 & $8.6 \%$ \\
\hline
\end{tabular}

\section{Results}

Multivariate normality was determined, and it revealed that there were no normality concerns in the data. The standard deviations of narrative advertisement (NA), purchase intention of Generation Z (PIGZ), persuasion knowledge (PK), and electronic word-of-mouth (eWOM) were 0.92374, 0.84417, 1.03189 , and 0.85724 respectively, which is in the acceptance range of +2 and -2 . The skewness values of the constructs NA, PIGZ, PK, and eWOM were found to be $0.166,-0.605,-0.081$, and -0.447 , respectively, which are also in the acceptable range of +1 and -1 . Lastly, kurtosis results of all the constructs were between the acceptable range of +3 and -3 . These results notify that there were no normality concerns in the data (see Table 2).

Table 2. Descriptive statistic outcomes.

\begin{tabular}{ccccccc}
\hline \multirow{2}{*}{ Variables } & Mean & SD & \multicolumn{2}{c}{ Skewness } & \multicolumn{2}{c}{ Kurtosis } \\
\cline { 2 - 7 } & Statistic & Statistic & Statistic & SE & Statistic & SE \\
\hline NA & 2.9763 & 0.92374 & 0.166 & 0.140 & -0.984 & 0.279 \\
PIGZ & 3.5395 & 0.84417 & -0.605 & 0.140 & -0.286 & 0.279 \\
PK & 3.0614 & 1.03189 & -0.081 & 0.140 & -0.921 & 0.279 \\
eWOM & 3.2188 & 0.85724 & -0.447 & 0.140 & -0.066 & 0.279 \\
\hline
\end{tabular}

Model estimation was done using SEM on AMOS 22.0. Initially, data normality, construct validity, reliability and exploratory factor analysis (EFA) was conducted on SPSS 24.0. After the attainment of 
positive outcomes of the respective tests, confirmatory factor analysis (CFA) was executed on AMOS. One of the key roles of CFA is a reaffirmation of reliability and validity through composite reliability (CR) and average variance extracted (AVE). CFA outcomes provided in Table 3 manifestly indicate that all the results were in the acceptable range. $\rho$ denotes EFA results, $\lambda$ presents standardized factor loadings, $\alpha$ illustrates Cronbach's alpha values, CR presents composite reliability values and AVE presents average variance extracted values. All the EFA $(\mathrm{P})$ values were above 0.4 , standardized factor loadings $(\lambda)$ were above $0.3, \alpha$ and CR values were above 0.7 , and AVE values were also above 0.4 (see Table 3 (see also Appendix A), Figure 1).

Table 3. CFA/ EFA factor loadings, reliability, and validity of measurement model $(n=304)$.

\begin{tabular}{cccccc}
\hline Constructs and Items & $\mathbf{P}$ & $\lambda$ & $\alpha$ & C.R & AVE \\
\hline Electronic Word of Mouth (eWOM) & & & 0.877 & 0.875 & 0.419 \\
eWOM1 & 0.521 & 0.585 & & & \\
eWOM2 & 0.548 & 0.542 & & & \\
eWOM3 & 0.423 & 0.457 & & & \\
eWOM4 & 0.583 & 0.592 & & \\
eWOM5 & 0.738 & 0.764 & & \\
eWOM6 & 0.828 & 0.754 & & \\
eWOM7 & 0.701 & 0.737 & & \\
eWOM8 & 0.658 & 0.549 & & & \\
eWOM9 & 0.712 & 0.746 & & & \\
eWOM10 & 0.486 & 0.662 & & & \\
Narrative Advertisement & & & 0.798 & 0.780 & \\
NA1 & 0.714 & 0.682 & & & \\
NA2 & 0.562 & 0.624 & & & \\
NA3 & 0.565 & 0.712 & & & \\
NA4 & 0.878 & 0.792 & & & \\
NA5 & 0.428 & 0.377 & & & \\
PIGZ1 & & & 0.821 & 0.507 & \\
PIGZ2 & 0.634 & 0.736 & & & \\
PIGZ3 & 0.697 & 0.762 & & & \\
PIGZ4 & 0.769 & 0.807 & & & \\
PIGZ5 & 0.766 & 0.657 & & & \\
PK1 & 0.506 & 0.371 & & & \\
PK2 & 0.742 & 0.761 & & & \\
PK3 & 0.733 & 0.795 & & & \\
Persuasion Knowledge & 0.569 & 0.622 & & & \\
\hline
\end{tabular}

The configuration of model fitness is another critical aspect of the measurement model. Incremental fit indices and absolute fit indices are the two further divisions of CFA. Standardized root mean squared residual (SRMR), adjusted goodness of fit index (AGFI), root mean square of approximation (RMSEA), chi-square/degree of freedom $(\chi 2 / \mathrm{df})$, and goodness of fit index (GFI) is determined in an absolute fit index. The values of SRMR and RMSEA were 0.055 and 0.059 , respectively, which are in the acceptable range (less than 0.08 ). The $\chi 2 / \mathrm{df}$ result was 2.053 , which is also in the acceptable range (1-3). Furthermore, GFI and AGFI values were 0.886 and 0.857 , which are also adequate $(<0.95)$. The outcomes of incremental fit indices revealed the TLI, NFI, CFI values to be $0.911,0.861$, and 0.923 , which are in the permissible range of less than 0.95 (see Figure 2). 


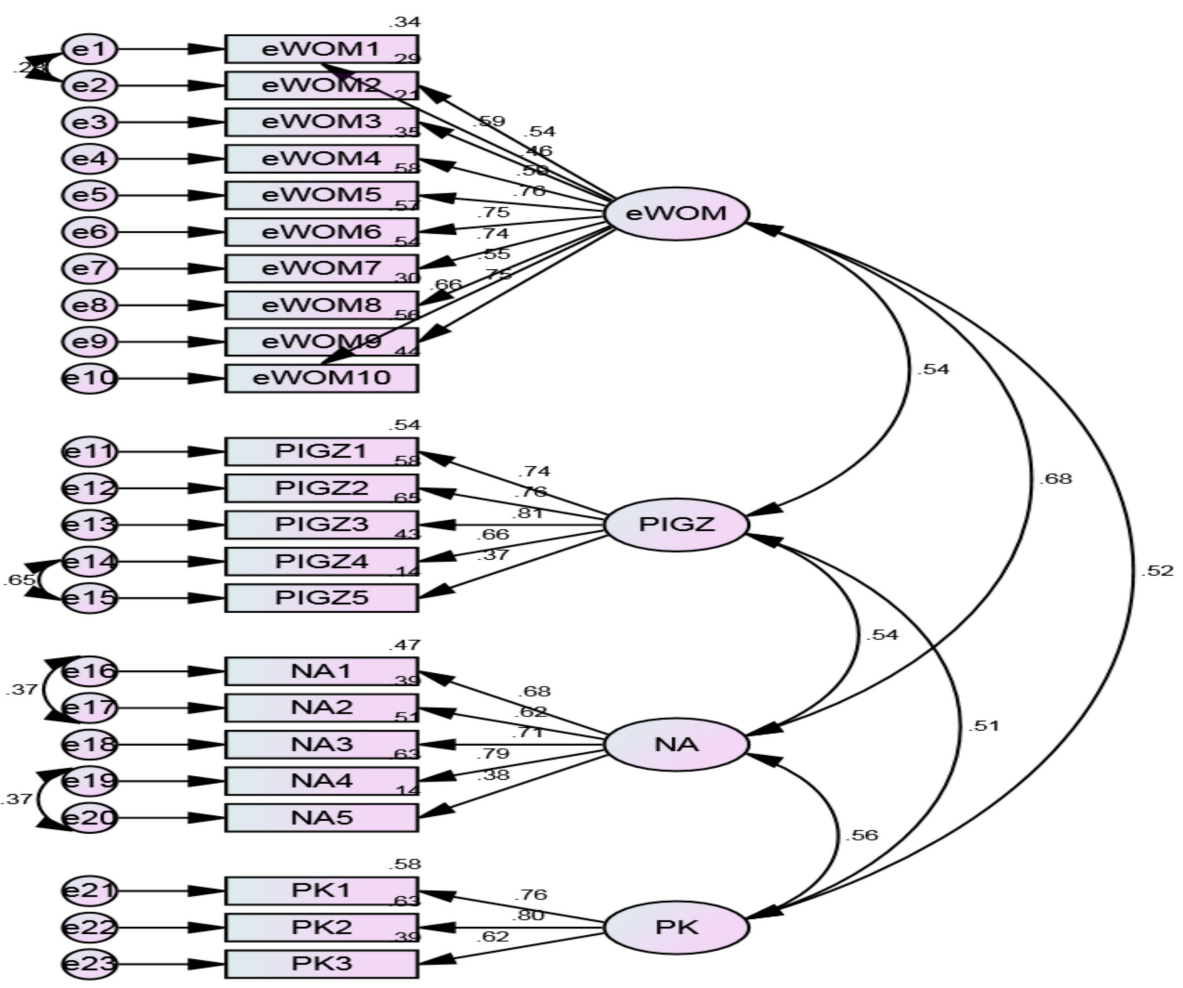

Figure 1. Confirmatory factor analysis (CFA).

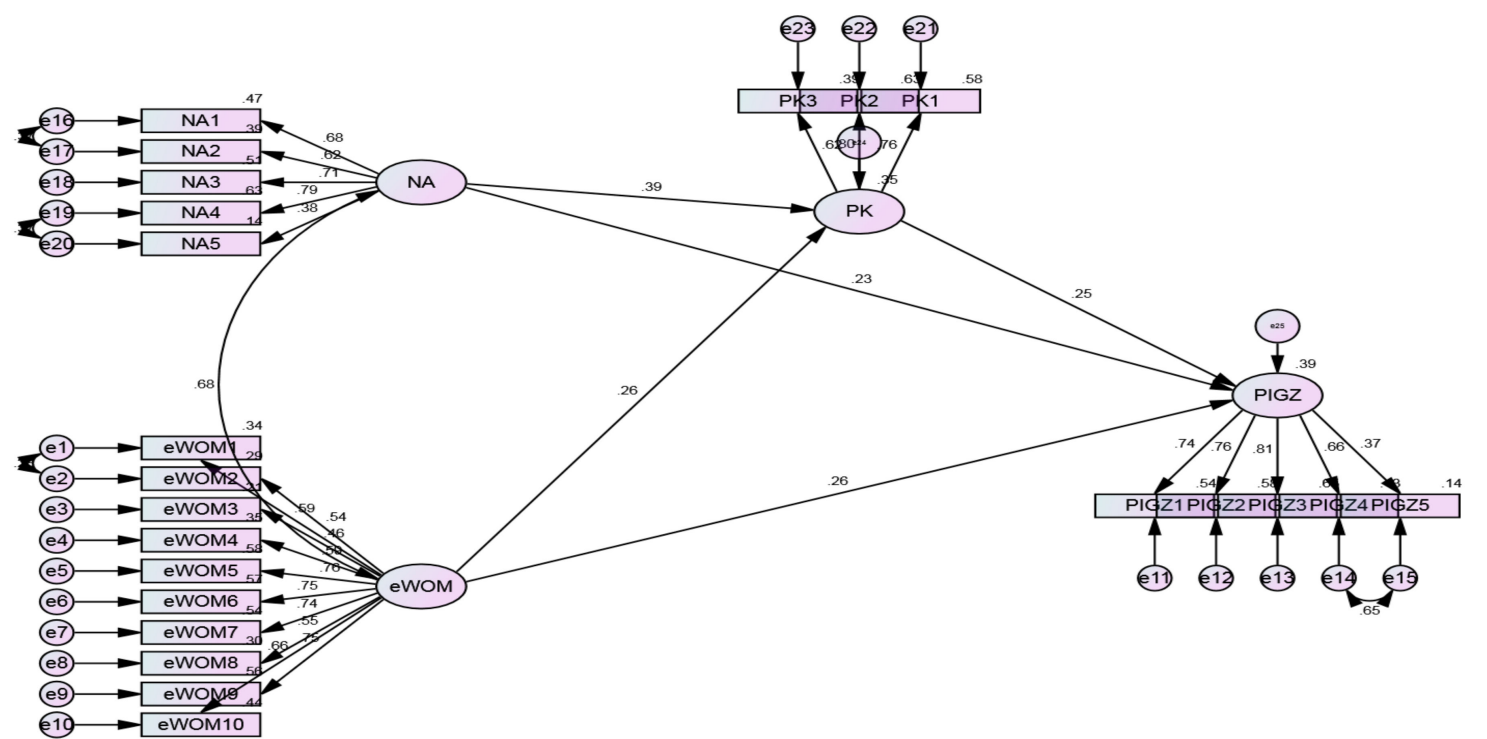

Figure 2. Structural Path Analysis: structural model fitness: P-Close: 0.030, Chi-square/degree of freedom: 2.053, probability level: 0.000, goodness of fit index: 0.886, adjusted goodness of fit: 0.857, Tucker-Lewis Coefficient: 0.901, comparative fit index: 0.923, normative fit index: 0.861, root mean square of approximation: 0.059 , and standardized root mean squared residual: 0.055 .

The discriminant and multicollinearity validity was estimated in which variance inflation factor (VIF) results were in the acceptable range of $1-5$, and maximum shared variance (MSV) outcomes were also in the permissible range of less than 1 . Moreover, square correlations in diagonals revealed that there were no validity concerns in the respective model (see Table 4 ). 
Table 4. Multicollinearity and discriminant validity $(\mathrm{N}=304)$.

\begin{tabular}{ccccccc}
\hline Constructs & VIF & MSV & NA & eWOM & PIGZ & PK \\
\hline NA & 1.639 & 0.465 & 0.643 & & & \\
eWOM & 1.563 & 0.465 & 0.682 & 0.647 & & \\
PIGZ & & 0.292 & 0.540 & 0.539 & 0.685 & \\
PK & 1.375 & 0.314 & 0.560 & 0.518 & 0.508 & 0.730 \\
\hline
\end{tabular}

The established hypotheses were consequently examined in the structural model where direct and indirect paths were examined. The direct paths of the first five hypotheses were quite significant as $\mathrm{H} 1, \mathrm{H} 2, \mathrm{H} 3, \mathrm{H} 4$, and $\mathrm{H} 5$ had path coefficients (beta values) of 0.329, 0.318, 0.386, 0.255, and 0.248 , respectively, with $t$-values greater than 1.96 , indicating acceptance of these hypotheses. The indirect effects of $\mathrm{H} 6$ and $\mathrm{H} 7$ provided path coefficient results of 0.227 and 0.256 , respectively. All the hypotheses had p-values of 0.00 which indicated the phenomenal significance of the hypothesized paths. Moreover, the regression result (R2) value of purchase intention of Generation Z (PIGZ) was 0.39 , and of narrative advertising (NA) was 0.35 (see Table 5). Lastly, the structural equation model fit measures are illustrated in Table 6, indicating $\chi 2 /$ DF, GFI, IFI, CFI, NFI, TLI, AGFI, RMSEA, and SRMR values to be in the acceptable range.

Table 5. Hypotheses outcomes.

\begin{tabular}{|c|c|c|c|c|c|}
\hline Hypotheses & Relationships & $\begin{array}{c}\text { Path } \\
\text { Coefficients }\end{array}$ & $t$-Statistics & $p$-Values & Results \\
\hline $\mathrm{H} 1$ & $\mathrm{NA} \rightarrow \mathrm{PIGZ}$ & 0.329 ** & 3.389 & $<0.01$ & Accepted \\
\hline $\mathrm{H} 2$ & $\mathrm{eWOM} \rightarrow$ PIGZ & $0.318^{* *}$ & 3.385 & $<0.01$ & Accepted \\
\hline H3 & $\mathrm{NA} \rightarrow \mathrm{PK}$ & $0.386^{* *}$ & 3.733 & $<0.01$ & Accepted \\
\hline $\mathrm{H} 4$ & $\mathrm{eWOM} \rightarrow \mathrm{PK}$ & $0.255^{* *}$ & 2.632 & $<0.01$ & Accepted \\
\hline H5 & $\mathrm{PK} \rightarrow \mathrm{PIGZ}$ & $0.248^{* *}$ & 3.027 & $<0.01$ & Accepted \\
\hline H6 & $\mathrm{NA} \rightarrow \mathrm{PK} \rightarrow \mathrm{PIGZ}$ & $0.227^{* *}$ & 2.251 & $<0.01$ & Accepted \\
\hline H7 & $\mathrm{eWOM} \rightarrow \mathrm{PK} \rightarrow \mathrm{PIGZ}$ & $0.256^{* *}$ & 2.771 & $<0.01$ & Accepted \\
\hline
\end{tabular}

Table 6. Structural equation model fit measures.

\begin{tabular}{cccccccccccc}
\hline Constructs & Chi-Square & DF & $\chi$ 2/DF & GFI & IFI & CFI & NFI & TLI & AGFI & RMSEA & SRMR \\
\hline Model & 451.619 & 220 & 2.053 & 0.886 & 0.923 & 0.923 & 0.861 & 0.911 & 0.857 & 0.059 & 0.077 \\
\hline
\end{tabular}

$\mathrm{DF}=$ Degree of freedom, $\chi 2 / \mathrm{DF}=$ Chi-square $/$ degree of freedom, AGFI $=$ adjusted goodness-of-fit index, TLI $=$ Tucker-Lewis Index, NFI = normed fit index, CFI = comparative fit index, IFI = incremental fit index, RMSEA = root mean square error of approximation, $\mathrm{SRMR}=$ standardized root mean square residual.

Purchase intention of Gen. $Z, R^{2}=0.39$, narrative advertising, $R^{2}=0.35$

\section{Discussion and Conclusions}

The results suggest that when the consumer is presented with a narrative advertisement, then it activates the use of persuasion knowledge, and it positively influences the purchase intention of Generation Z. Prior studies have reflected diverse results about the effect of persuasion knowledge, some researchers found its influence negative, while others showed that activation of persuasion knowledge helped increase brand memory and loyalty. Due to the deterioration in the attention spans of consumers, it remains pertinent to investigate whether narrative advertising has a future or not. As of 2020, the attention span of individuals has been reduced to 0.825 seconds. There is an element of storytelling in narrative advertising, which consequently requires longer advertisements $[93,94]$. Thus, the study oriented to precisely measure whether the size of narrative advertising affects Generation $\mathrm{Z}$ as per the theoretical directions provided in the prior studies. The results reveal that Generation $Z$ 's purchase intention is influenced when they are presented with narrative advertising. eWOM 
also plays a significant role when Gen Z make their purchasing decisions. Similarly, eWOM being an interesting evolving phenomenon remains a critical factor to determine along with narrative advertising. Interestingly, the direct effects of eWOM on purchase intentions were slightly less as compared to the impact of narrative advertising. However, the mediation of persuasion knowledge between eWOM and purchase intentions was found to be strong. The Generation $\mathrm{Z}$ cohort is quickly taking over the marketplace, and their particular online habits and traits need different marketing strategies to capture their attention. In this context, the research gives insight into how to create an online marketing strategy that resonates with Generation Z. As digital platforms have empowered the consumers in a way that they can control when and where they can avoid the marketing material to interrupt their entertainment, marketers needs to make advertising entertaining in itself. By employing storylines in advertising, marketers can better target this generation, as narrative advertisements can trigger emotions, eventually leading to capturing their attention. Meanwhile, by using the interactive nature of digital platforms, marketers must participate in a two-way dialogue with their audience. As eWOM plays an important role in the decision making of the consumer, digital presence, and positive image are important to capture the attention of Generation $\mathrm{Z}$ consumers. The study is beneficial for the practitioners as it would be providing insights to the marketers that how narrative advertising can boost purchase intentions. Generation $\mathrm{Z}$ is reckoned to be a difficult generation to target by the marketers; henceforth, the paper provides directions of how Generation $Z$ can be influenced through narrative advertising and eWOM with the mediation of persuasion knowledge. The study would be beneficial for upcoming entrepreneurs too. While designing their marketing strategies, they can make effective use of the cyclical dynamics of open innovation, i.e., deploying eWOM and narrative advertising simultaneously.

\section{Future Research Directions}

The research is insightful in understanding narrative advertising and electronic word-of-mouth, and how particularly Generation $\mathrm{Z}$ is influenced by these. Yet, certain limitations need to be recognized and thus are presented in this section. Firstly, the research is cross-sectional and it would be more significant to study the same variables in longitudinal research as a better understanding can be achieved through longitudinal research to study the behaviors of individuals. This research also took a generic approach considering the online ads that are being displayed on various digital platforms, the same research could be done under controlled settings. For future studies, the narrative advertising effect could be further examined by using different thought protocols; for instance, how prior brand attitude will affect the narrative advertisement process. Furthermore, antecedents of narrative advertising should be unfolded, and dimensional effect should be determined. The impact of narrative and non-narrative advertisements on the purchase intentions of Generation $\mathrm{Z}$ must be explored in future studies. Simultaneously determining the effects of narrative and non-narrative advertisements would provide a concrete holistic picture of the subject matter. In terms of digital interaction, eWOM in generic milieu was considered, while future studies could be conducted in a specific product category, or low and high involvement products and how narrative advertising and eWOM can influence in these settings. Lastly, both the effects of narrative advertisement and eWOM could be studied during an actual marketing campaign.

Author Contributions: Conceptualization, S.T., M.G.K., and U.Z.; methodology, M.G.K., U.Z.; software, M.G.K.; validation, M.G.K.; formal analysis, M.G.K.; investigation, S.T, M.G.K.; resources, M.G.K., U.Z.; data curation, S.T; writing—original draft preparation, S.T, M.G.K., and U.Z.; writing—review and editing, S.T., M.G.K., U.Z.; project administration, M.G.K., and U.Z. All authors have read and agreed to the published version of the manuscript.

Funding: This research received no external funding.

Conflicts of Interest: The authors declare no conflict of interest. 


\section{Appendix A}

\section{Constructs and Items}

\section{Narrative Advertisement}

i. Ad made me imagine myself using the product.

ii. Ad is relevant to me personally.

iii. Ad made me think about my experiences in life.

iv. I have control over my experience while watching an online ad.

v. While watching an online ad, I can choose freely what I want to see.

\section{Persuasion Knowledge}

i. The aim of online ads/reviews is to influence my opinion.

ii. The aim of online ads/reviews is to make people like certain products/services.

iii. After viewing an online ad/review and recommendation, I feel I have been accurately informed.

\section{Purchase Intention of Gen. Z}

i. I will buy products that are advertised on social media in the near future.

ii. I desire to buy products that are promoted on social media.

iii. Advertisements on social media have a positive influence on my purchase decisions.

iv. I would buy the products that are advertised on social media if I had the money.

v. I am likely to purchase some of the products that are advertised on digital media

\section{Electronic word-of-mouth (eWOM)}

i. I find review arguments to be convincing.

ii. I find review arguments to be persuasive.

iii. Based on the reviewer rating, I believe a reviewer is reputable.

iv. Based on the reviewer rating, I believe a reviewer is trustworthy.

v. Information from a reviewer contradicted what I had known before reading it.

vi. The reviewer supported my impression of the discussed product.

vii. Comments in the review are consistent with other reviews.

viii. Comments in the review are similar to other reviews.

ix. The information on social media platforms is informative

x. The information about products that are shared by my friends on social media is understandable.

\section{References}

1. Duffett, R. The YouTube Marketing Communication Effect on Cognitive, Affective and Behavioural Attitudes among Generation Z Consumers. Sustainability 2020, 12, 5075. [CrossRef]

2. Haddouche, H.; Salomone, C. Generation $Z$ and the tourist experience: Tourist stories and use of social networks. J. Tour. Futures 2018, 4, 69-79. [CrossRef]

3. Bashir, S.; Khwaja, M.G.; Rashid, Y.; Turi, J.A.; Waheed, T. Green Brand Benefits and Brand Outcomes: The Mediating Role of Green Brand Image. SAGE Open 2020, 10, 1-11. [CrossRef]

4. Widyanto, H.A.; Agusti, C.R. Beauty influencer in the digital age: How does it influence purchase intention of generation Z? Jurnal Manajemen dan Pemasaran Jasa 2020, 13, 1-16. [CrossRef] 
5. Pitardi, V.; Dessart, L. Narrative advertising: How language concreteness affects willingness to advise. In Proceedings of the 47th Annual Conference of the European Marketing Academy (EMAC), Glasgow, UK, 29 May-2 June 2018; European Marketing Academy (EMAC): Brussels, Belgium, 2018.

6. Chu, C.; Kim, J. The current state of knowledge on electronic word-of-mouth in advertising research. Int. J. Advert. 2018, 37, 1-13. [CrossRef]

7. Mahmood, S.; Khwaja, M.G.; Jusoh, A. Electronic Word of Mouth on Social Media Websites: Role of Social Capital Theory, Self-Determination Theory, and Altruism. Int. J. Space-Based Situated Comput. 9, 1-13.

8. Kamenidou, I.C.; Mamalis, S.A.; Pavlidis, S.; Bara, E.Z.G. Segmenting the generation Z cohort university students based on sustainable food consumption behavior: A preliminary study. Sustainability 2019, 11, 837. [CrossRef]

9. Khwaja, M.G. Is Electronic Word of Mouth (eWOM) the future of modern marketing? Empirical evidences from the emerging markets! In Shapes of Futures_Interdisciplinary Conference; University of Bielsko-Biała: Bielsko-Biała, Poland, 2019.

10. Zheng, L.; Phelps, J.E.; Pimentel, D. Psychological Transportation in Narrative Advertising. Advert. Theory 2019, 4, 53-69.

11. Anaza, N.A.; Kemp, E.; Briggs, E.; Borders, A.L. Tell me a story: The role of narrative transportation and the C-suite in B2B advertising. Ind. Mark. Manag. 2019, 89, 605-618. [CrossRef]

12. Huang, R.; Ha, S.; Kim, S.H. Narrative persuasion in social media: An empirical study of luxury brand advertising. J. Res. Interact. Mark. 2018, 12, 274-292. [CrossRef]

13. Khwaja, M.G.; Jusoh, A.; Nor, K.M. Does online social presence lead to purchase intentions? Int. J. Econ. Policy Emerg. Econ. 2019, 12, 198-206. [CrossRef]

14. Cohen, A.C.; Dromi, S.M. Advertising morality: Maintaining moral worth in a stigmatized profession. Theory Soc. 2018, 47, 175-206. [CrossRef]

15. Bolat, N. The Irony as a Narrative Advertising Strategy. In Handbook of Research on Narrative Advertising; IGI Global: Hershey, PA, USA, 2019; pp. 270-280.

16. Kang, J.A.; Hong, S.; Hubbard, G.T. The role of storytelling in advertising: Consumer emotion, narrative engagement level, and word-of-mouth intention. J. Consum. Behav. 2020, 19, 47-56. [CrossRef]

17. Khwaja, M.G.; Mahmood, S.; Jusoh, A. The impacts of Quality Management on Customer Focus in the Beverages Industry. Proc. Eng. Sci. 2020, 2, 81-92. [CrossRef]

18. Hussain, S.; Ahmed, W.; Jafar, R.M.S.; Rabnawaz, A.; Jianzhou, Y. eWOM source credibility, perceived risk and food product customer's information adoption. Comput. Hum. Behav. 2017, 66, 96-102. [CrossRef]

19. PTA. Pakistan Telecom Indicators. PTA Online; 2020. Available online: https://www.pta.gov.pk/en/telecomindicators (accessed on 14 September 2020).

20. Data Reportal. Digital 2020: Pakistan. Data Reportal Online. 2020. Available online: https://datareportal. com/reports/digital-2020-pakistan (accessed on 5 November 2020).

21. Nguyen, X.T. Factors impacting on Korean consumer goods purchase decision of Vietnam's generation Z. J. Distrib. Sci. 2020, 17, 61-71. [CrossRef]

22. Khwaja, M.G.; Zaman, U. Configuring the Evolving Role of eWOM on the Consumers Information Adoption. J. Open Innov. Technol. Mark. Complex. 2020, 6, 125. [CrossRef]

23. Menon, R.V.; Sigurdsson, V.; Larsen, N.M.; Fagerstrøm, A.; Sørensen, H.; Marteinsdottir, H.G.; Foxall, G.R. How to grow brand post engagement on Facebook and Twitter for airlines? An empirical investigation of design and content factors. J. Air Transp. Manag. 2019, 79, 101678.

24. Kim, E.; Ratneshwar, S.; Thorson, E. Why narrative ads work: An integrated process explanation. J. Advert. 2017, 46, 283-296. [CrossRef]

25. Liang, Y.; Tukachinsky, R.H. Narrative Persuasion 2.0: Transportation in Participatory Websites. Commun. Res. Rep. 2017, 34, 201-210. [CrossRef]

26. Bashir, S.; Khwaja, M.G.; Turi, J.A.; Toheed, H. Extension of planned behavioral theory to consumer behaviors in green hotel. Heliyon 2019, 5, e02974. [CrossRef]

27. Braddock, K.; Dillard, J.P. Meta-analytic evidence for the persuasive effect of narratives on beliefs, attitudes, intentions, and behaviors. Commun. Monogr. 2016, 83, 446-467. [CrossRef]

28. Murphy, S.T.; Frank, L.B.; Chaterjee, J.S.; Baezconde-Garbanati, L. Narrative versus Non narrative: The Role of Identification, Transportation, and Emotion in Reducing Disparities. J. Commun. 2017, 63, 116-137. [CrossRef] [PubMed] 
29. Wojcieszak, M.; Kim, N. How to improve attitudes toward disliked groups: The effects of narrative versus numerical evidence on political persuasion. Commun. Res. 2016, 43, 785-809. [CrossRef]

30. Christy, K.R. I, You, or He: Examining the Impact of Point of View on Narrative Persuasion. Media Psychol. 2017, 21, 700-718. [CrossRef]

31. Ma, Z.; Nan, X. Friends don't let friends smoke: How storytelling and social distance influence nonsmokers' responses to antismoking messages. Health Commun. 2018, 33, 887-895. [CrossRef]

32. Hamby, A.; Brinberg, D. Happily ever after: How ending valence influences narrative persuasion in cautionary stories. J. Advert. 2016, 45, 498-508. [CrossRef]

33. Hamby, A.; Brinberg, D.; Daniloski, K. Reflecting on the journey: Mechanisms in narrative persuasion. J. Consum. Psychol. 2017, 27, 11-22. [CrossRef]

34. Khwaja, M.G.; Mahmood, S.; Zaman, U. Examining the Effects of eWOM, Trust Inclination, and Information Adoption on Purchase Intentions in an Accelerated Digital Marketing Context. Information 2020, 11, 478. [CrossRef]

35. Erdem, M.N. Narrative 3.0: Generating of user integrated narrative. In Brand Culture and Identity: Concepts, Methodologies, Tools, and Applications; IGI Global: Hershey, PA, USA, 2019; pp. 759-778.

36. Silva, M.J.D.B.; Farias, S.A.D.; Grigg, M.K.; Barbosa, M.D.L.D.A. Online engagement and the role of digital influencers in product endorsement on Instagram. J. Relatsh. Mark. 2020, 19, 133-163. [CrossRef]

37. Mohammed, A.B. Selling smartphones to generation Z: Understanding factors influencing the purchasing intention of smartphone. Int. J. Appl. Eng. Res. 2018, 13, 973-4562.

38. Sirer, E. Stadiums as a Narrative Space in Advertising. In Handbook of Research on Narrative Advertising; IGI Global: Hershey, PA, USA, 2019; pp. 57-65.

39. Lissitsa, S.; Kol, O. Four generational cohorts and hedonic m-shopping: Association between personality traits and purchase intention. Electron. Commer. Res. 2019, 21, 1-26. [CrossRef]

40. Thomas, M.R.; Mathew, J. Online merchandising cues influencing the purchase intention of generation $\mathrm{Z}$ mediated by emotions using-SOR framework. Asian J. Manag. 2018, 9, 175-182. [CrossRef]

41. Wu, T.J.; Xu, T.; Li, L.Q.; Yuan, K.S. "Touching with heart, reasoning by truth"! The impact of Brand cues on mini-film advertising effect. Int. J. Advert. 2020, 1-29. [CrossRef]

42. Kim, S.J.; Maslowska, E.; Malthouse, E.C. Understanding the effects of different review features on purchase probability. Int. J. Advert. 2017, 37, 29-53. [CrossRef]

43. Von Helversen, B.; Abramczuk, K.; Kopeć, W.; Nielek, R. Influence of consumer reviews on online purchasing decisions in older and younger adults. Decis. Support Syst. 2018, 113, 1-10. [CrossRef]

44. Khwaja, M.G.; Jusoh, A.; Nor, K.M. Investigating the Effects of Social Presence on Purchase Intentions in the Emerging Market: An Empirical Investigation. In Proceedings of the SIBR-Thammasat 2018 Bangkok Conference on Interdisciplinary Business and Economics Research 2018, Bangkok, Thailand, 16-17 June 2018.

45. Lal, S.; Rathore, M.K. The effects of television advertisements on adolescents: An exploratory study. Indian J. Health Wellbeing 2018, 9, 833-836.

46. Bhandari, M.; Rodgers, S. Effects of Brand Feedback to Negative eWOM on Attitude toward the Product. Southwestern Mass. Commun. J. 2017, 32, 2-9.

47. Hennig-Thurau, T.; Gwinner, K.P.; Walsh, G.; Gremler, D.D. Electronic word-of-mouth via consumer-opinion platforms: What motivates consumers to articulate themselves on the internet? J. Interact. Mark. 2004, 18, 38-52. [CrossRef]

48. Khwaja, M.G.; Jusoh, A.; Nor, K.M. Investigating Social Media Marketing Impacts On Consumer Behaviours With The Moderating Effects Of Negative Viral Marketing: Empirical Evidences From Emerging Markets. In Proceedings of the 10th Malaysia International Conference on Languages, Literature's and Cultures, Malacca, Malaysia, 14-16 August 2018.

49. Thomas, M.R.; Kavya, V.; Monica, M. Online website cues influencing the purchase intention of generation z mediated by trust. Indian J. Commer. Manag. Stud. 2018, 9, 13-23. [CrossRef]

50. Lim, X.J.; Radzol, A.M.; Cheah, J.; Wong, M.W. The impact of social media influencers on purchase intention and the mediation effect of customer attitude. Asian J. Bus. Res. 2017, 7, 19-36. [CrossRef]

51. Djafarova, E.; Rushworth, C. Exploring the credibility of online celebrities' Instagram profiles in influencing the purchase decisions of young female users. Comput. Hum. Behav. 2017, 68, 1-7. [CrossRef]

52. Erkan, I.; Evans, C. The influence of eWOM in social media on consumers' purchase intentions: An extended approach to information adoption. Comput. Hum. Behav. 2016, 61, 47-55. [CrossRef] 
53. Farzin, M.; Fattahi, M. eWOM through social networking sites and impact on purchase intention and brand image in Iran. J. Adv. Manag. Res. 2018, 15, 161-183. [CrossRef]

54. Nieto-García, M.; Muñoz-Gallego, P.A.; González-Benito, Ó. Tourists' willingness to pay for an accommodation: The effect of eWOM and internal reference price. Int. J. Hosp. Manag. 2017, 62, 67-77. [CrossRef]

55. Ansary, A.; Hashim, N.M.H.N. Brand image and equity: The mediating role of brand equity drivers and moderating effects of product type and word of mouth. Rev. Manag. Sci. 2018, 12, 969-1002. [CrossRef]

56. Araujo, T.; Neijens, P.; Vliegenthart, R. Getting the word out on Twitter: The role of influentials, information brokers and strong ties in building word-of-mouth for brands. Int. J. Advert. 2017, 36, 496-513. [CrossRef]

57. Knoll, J. Advertising in social media: A review of empirical evidence. Int. J. Advert. 2016, 35, $266-300$. [CrossRef]

58. Hussain, S.; Song, X.; Niu, B. Consumers' Motivational Involvement in eWOM for Information Adoption: The Mediating Role of Organizational Motives. Front. Psychol. 2019, 10, 1-13. [CrossRef]

59. Khwaja, M.G. The Impacts of Quality Management on Performance: A Case Study of Kohinoor Textile Mills Limited, Rawalpindi, Pakistan. Int. J. Cont. Res. Bus. 2014, 5, 358-382.

60. Ellison, B.T.; Padgett, B.C.; Fowler, D.C. Social Media Celebrity Endorsements Effect on Generation Z's Purchase Intentions. In International Textile and Apparel Association Annual Conference Proceedings 2017; Iowa State University Digital Press: Ames, IA, USA, 2017.

61. Kudeshia, C.; Kumar, A. Social eWOM: Does it affect the brand attitude and purchase intention of brands? Manag. Res. Rev. 2017, 40, 310-330. [CrossRef]

62. Khwaja, M.G.; Jusoh, A.; Nor, K.M. How Electronic Word of Mouth (eWOM) leads to Information Adoption? In Proceedings of the 6th GSOM Emerging Markets Conference-2019, St. Petersburg, Russia, 3-5 October 2019.

63. Su, C.H.J.; Tsai, C.H.K.; Chen, M.H.; Lv, W.Q. US sustainable food market generation Z consumer segments. Sustainability 2019, 11, 3607. [CrossRef]

64. Bartsch, A.; Klob, A. Personalized charity advertising. Can personalized prosocial messages promote empathy, attitude change, and helping intentions toward stigmatized social groups? Int. J. Adv. 2019, 38, 345-363. [CrossRef]

65. Zhang, W.; Watts, S. Knowledge adoption in online communities of practice. In Proceedings of the ICIS 2003, Seattle, WA, USA, 15-17 December 2003; p. 9.

66. Friestad, M.; Wright, P. Everyday persuasion knowledge. Psychol. Mark. 1999, 16, 185-194. [CrossRef]

67. Wojdynski, B.W.; Evans, N.J. Going native: Effects of disclosure position and language on the recognition and evaluation of online native advertising. J. Advert. 2016, 45, 157-168. [CrossRef]

68. Van Reijmersdal, E.A.; Tutaj, K.; Boerman, S.C. The effects of brand placement disclosures on skepticism and brand memory. Communications 2013, 38, 127-146. [CrossRef]

69. Reijmersdal, E.A.; Lammers, N.; Rozendaal, E.; Buijzen, M. Disclosing the persuasive nature of advergames: Moderation effects of mood on brand responses via persuasion knowledge. Int. J. Advert. 2015, 34, 70-84. [CrossRef]

70. Royo, M.; Chulvi, V.; Mulet, E.; Galán, J. Users' reactions captured by means of an EEG headset on viewing the presentation of sustainable designs using verbal narrative. Eur. J. Mark. 2018, 52, 159-181. [CrossRef]

71. Boerman, S.C.; van Reijmersdal, E.A.; Neijens, P.C. Effects of Sponsorship Disclosure Timing on the Processing of Sponsored Content: A Study on the Effectiveness of European Disclosure Regulations. Psychol. Mark. 2014, 31, 214-224. [CrossRef]

72. Campbell, M.C.; Mohr, G.S.; Verlegh, P.W. Can disclosures lead consumers to resist covert persuasion? The important roles of disclosure timing and type of response. J. Consum. Psychol. 2013, 23, 483-495. [CrossRef]

73. Brusse, E.D.A.; Fransen, M.L.; Smit, E.G. Framing in entertainment-education: Effects on processes of narrative persuasion. Health Commun. 2017, 32, 1501-1509. [CrossRef]

74. Hamby, A.; Brinberg, D. Cause-Related Marketing Persuasion Knowledge: Measuring Consumers' Knowledge and Ability to Interpret CrM Promotions. J. Consum. Aff. 2018, 52, 373-392. [CrossRef]

75. Sethi, R.S.; Kaur, J.; Wadera, D. Purchase intention survey of millennials towards online fashion stores. Acad. Mark. Stud. J. 2018, 22, 1-16. 
76. Kunja, S.R.; Gvrk, A. Examining the effect of eWOM on the customer purchase intention through value co-creation (VCC) in social networking sites (SNSs): A study of select Facebook fan pages of smartphone brands in India. Manag. Res. Rev. 2018, 43, 245-269. [CrossRef]

77. Lee, Y.K. The Relationship between Green Country Image, Green Trust, and Purchase Intention of Korean Products: Focusing on Vietnamese Gen Z Consumers. Sustainability 2020, 12, 5098. [CrossRef]

78. Khwaja, M.G. Determining the impacts of Ketchup Industry rebranding on Customer Satisfaction levels: A Case Study. In Proceedings of the 20th National Research Conference, Islamabad, Pakistan, 19 April 2017.

79. Dalamu, T. Narrative in advertising: Persuading the Nigerian audience within the schemata of storyline. Anu. Filol. Lleng. Lit. Mod. 2017, 39, 19-45.

80. Vafeiadis, M.; Li, R.; Shen, F. Narratives in political advertising: An analysis of the political advertisements in the 2014 midterm elections. J. Broad. Electron. Med. 2018, 62, 354-370. [CrossRef]

81. Purwanto, S.; Hartini, S.; Premananto, G.C. Narrative Online Advertising as External Variable in the Development of the Technology Acceptance Model of Go-Pay for Millennials. J. Account. Strateg. Financ. 2020, 3, 118-135.

82. Heejae, S.; Dahana, W.D. The Moderating Roles of Prior Attitude and Message Acceptance in Electronic Word of Mouth. Int. J. Bus. Inf. 2017, 12, 183-187.

83. Burnkrant, R.E.; Unnava, H.R. Effects of self-referencing on persuasion. J. Consum. Res. 1995, 22, 17-26. [CrossRef]

84. Rozendaal, E.; Buijzen, M.; Valkenburg, P. Comparing children's and adults' cognitive advertising competences in the Netherlands. J. Child. Med. 2010, 4, 77-89. [CrossRef]

85. Zaman, U.; Jabbar, Z.; Nawaz, S.; Abbas, M. Understanding the soft side of software projects: An empirical study on the interactive effects of social skills and political skills on complexity-performance relationship. Int. J. Proj. Manag. 2019, 37, 444-460. [CrossRef]

86. Zaman, U.; Nawaz, S.; Tariq,S.; Humayoun, A.A. Linking transformational leadership and "multi-dimensions" of project success: Moderating effects of project flexibility and project visibility using PLS-SEM. Int. J. Manag. Proj. Bus. 2019, 13, 103-127. [CrossRef]

87. Lowry, P.B.; Gaskin, J. Partial least squares (PLS) structural equation modeling (SEM) for building and testing behavioral causal theory: When to choose it and how to use it. IEEE Trans. Prof. Commun. 2014, 57, 123-146. [CrossRef]

88. Kim, S.; Choi, M.J.; Choi, J.S. Empirical Study on the Factors Affecting Individuals' Switching Intention to Augmented/Virtual Reality Content Services Based on Push-Pull-Mooring Theory. Information 2020, 11, 25. [CrossRef]

89. Kim, S.; Kim, B.; Seo, M. Impacts of Sustainable Information Technology Capabilities on Information Security Assimilation: The Moderating Effects of Policy-Technology Balance. Sustainability 2020, 12, 6139. [CrossRef]

90. Obrad, C. Constraints and Consequences of Online Teaching. Sustainability 2020, 12, 6982. [CrossRef]

91. Domínguez-Amorós, M.; Aparicio-Chueca, P. Lack of Association between the Reasons for and Time Spent Doing Physical Activity. Int. J. Environ. Res. Public Health 2020, 17, 6777. [CrossRef]

92. Zaman, U. Examining the effect of xenophobia on "transnational" mega construction project (MCP) success: Moderating role of transformational leadership and high-performance work (HPW) practices. Eng. Constr. Archit. Manag. 2020, 27, 119-1143. [CrossRef]

93. Lies, J. Marketing Intelligence and Big Data: Digital Marketing Techniques on their Way to Becoming Social Engineering Techniques in Marketing. Int. J. Interact. Multimed. Artif. Intell. 2019, 5, 134-144. [CrossRef]

94. Morcillo, F.M. Happiness and technology: Special consideration of digital technology and internet. IJIMAI 2018, 5, 162-168.

Publisher's Note: MDPI stays neutral with regard to jurisdictional claims in published maps and institutional affiliations. 